\title{
PENGARUH MAQASHID SYARIAH INDEX DAN ISLAMIC SOCIAL REPORTING TERHADAP PROFITABILITAS BANK SYARIAH DI INDONESIA PERIODE 2016 - 2019
}

Selamet Eko Budi Santoso*

\section{RAAR $\left.\right|_{\text {Accounting Research }} ^{\text {Reviled }}$ \\ Affiliation: \\ Accounting Department, Universitas Muhammadiyah \\ Purwokerto, Indonesia \\ *Correspondence: \\ Budi.imm@gmail.com}

Article Process:

Submitted:

January 31, 2022

Reviewed:

February 4, 2022

Revised:

February 10, 2022

Accepted:

February 12, 2022

Published:

February 15, 2022

\section{Citation:}

Santoso. Selamet Eko Budi. (2022). Pengaruh Maqashid Syariah Index Dan Islamic Social Reporting Terhadap Profitabilitas Bank Syariah Di Indonesia Periode 2016 - 2019. RAAR: Review of Applied Accounting Research, 2 (1), 304-315.

\section{Office Address:}

Jl. K.H. Ahmad Dahlan, Dukuhwaluh, Kec.

Kembaran, Kabupaten

Banyumas, Jawa Tengah

53182

e-ISSN : 2807-8969

\begin{abstract}
ABSTRAK
Penelitian ini bertujuan untuk menguji dan menganalisis pengaruh maqashid syariah index terhadap dan Islamic social reporting, terhadap profitabilitas bank syariah di Indonesia. Dalam penelitian ini, profitabilitas diukur dengan menggunakan ROA (Return On Asset). sampel penelitian ini adalah bank umum syariah nasional di Indonesia yang terdaftar di Otoritas Jasa Keuangan tahun 2016-2019, sebanyak 14 bank syariah. Hasil penelitian ini menunjukan bahwa Maqashid syariah index berpengaruh positif terhadap profitabilitas bank umum syariah. Sedangkan Islamic social reporting, tidak berpengaruh terhadap profitabilitas bank umum syariah.
\end{abstract}

Kata kunci: maqashid syariah index, Islamic Social Reporting, profitabilitas.

\section{ABSTRACT}

This study aims to examine and analyze the effect of the maqashid sharia index and Islamic social reporting on the profitability of Islamic banks in Indonesia. In this study, profitability is measured using ROA (Return On Assets). The sample of this study is the national Islamic commercial bank in Indonesia registered with the Financial Services Authority in 20162019, as many as 14 Islamic banks. The results of this study indicate that the Maqashid sharia index has a positive effect on the profitability of Islamic commercial banks. Meanwhile, Islamic social reporting has no effect on the profitability of Islamic commercial banks.

Keywords: maqashid sharia index, Islamic Social Reporting, profitability.

\section{PENDAHULUAN}

Otoritas Jasa Keuangan menyebut industri keuangan syariah memiliki daya tahan yang lebih tinggi terhadap dampak pandemi Covid-19. Hal ini terbukti dari pertumbuhan aset industri keuangan syariah hingga Juli 2020 mencapai Rp 1.639 triliun, tumbuh $20,61 \%$ dibandingkan periode yang sama tahun lalu. Ketua OJK Wimboh Santoso menjelaskan jumlah aset keuangan syariah tersebut tidak termasuk saham syariah. Adapun pangsa pasar industri keuangan syariah saat ini mencapai 9,68\%. (https://katadata.co.id, 2020).

Pertumbuhan yang tinggi tersebut didukung oleh meningkatnya jumlah lembaga keuangan syariah di Indonesia, misalnya pada sektor perbankan, terdapat 14 bank 
umum syariah, 20 unit usaha syariah, dan 162 BPR syariah. Di sektor pasar modal, terdapat 464 saham syariah yang beredar, 145 sukuk korporasi, 282 reksadana syariah, dan 66 sukuk negara. Sementara di industri jasa keuangan nonbank terdapat 215 lembaga jasa keuangan syariah termasuk didalamnya perusahaan asuransi, pembiayaan, penjaminan dan lembaga keuangan mikro syariah.

Dalam ajaran Islam terdapat konsep maqasid syariah sebagai tujuan hukum Islam yang berlaku. Maqasid syariah menekankan pada perlindungan agama (din), intelek ('aql), hidup (nafs), garis keturunan (nasl), dan kekayaan (māl). Mahmoud dan Razak (2008) mengembangkan Maqasid Syaria Index (MSI) untuk bank syariah, terdiri dari Pengukuran Pendidikan Individu (Educating Individuals), Menegakkan Keadilan (Justice Enforce), dan Kepentingan Umum (Maslahah).

Bank syariah dalam operasionalnya harus memperhatikan maqasid dalam kegiatan usahanya, terutama perlindungan dan peningkatan kualitas aset serta semua barang dan jasa yang memiliki nilai ekonomis. Selain itu, Bank Syariah juga harus memperhatikan tanggungjawab sosial, sebagai upaya perlindungan perusahaan kepada masyarakat disekitarnya. Maqasid Syariah juga menunjukkan bahwa bank syariah dalam operasionalnya harus mempunyai tanggung jawab sosial karena bank syariah mempunyai kewajiban untuk menciptakan manfaat sosial. Islamic Social Reporting (ISR) merupakan bentuk laporan aktifttas tanggungjawab sosial bank syariah. Untuk tujuan ini, ada Indeks yang memasukkan komponen-komponen yang terdiri dari investasi, keuangan, produk, dan jasa; Komponen tersebut adalah penilaian investasi dan keuangan, produk dan layanan, insentif tenaga kerja, manfaat sosial, manfaat lingkungan, dan tata kelola organisasi yang baik. Perumusan masalah dalam penelitian ini adalah :

a. Apakah Maqashid Syaiah Index ini berpengaruh positif terhadap profitabilitas bank syariah di Indonesia?

b. Apakah Islamic Sosial Reporting berpengaruh positif terhadap profitabilitas bank syariah di Indonesia?

\section{TINJAUAN PUSTAKA}

\section{A. Teori Stakeholder}

Ghozali dan Chariri (2007:409) menyatakan bahwa dalam teori Stakeholder Perusahaan bukanlah entitas yang hanya beroperasi untuk kepentingannya sendiri namun harus memberikan manfaat bagi para stakeholder (pemegang saham, kreditor, konsumen, supplier, pemerintah, masyarakat, dan pihak lain). Dengan demikian, maka keberadaan suatu perusahaan sangat dipengaruhi oleh dukungan yang diberikan oleh stakeholder kepada perusahaan tersebut. Teori Stakeholder mampu menjelaskan antara hubungan perusahaan dengan stakeholder-nya. Stakeholder pada dasarnya dapat mengendalikan atau memiliki kemampuan untuk mempengaruhi pemakaian sumbersumber ekonomi yang digunakan perusahaan. Oleh karena itu power stakeholder ditentukan oleh besar kecilnya power yang dimiliki stakeholder atas sumber tersebut. Dengan kata lain, teori ini menyatakan bahwa kesuksesan dan hidup matinya suatu perusahaan sangat tergantung pada kemampuannya menyeimbangkan beragam kepentingan dari para stakeholder atau 
pemangku kepentingan. Jika mampu, maka perusahaan akan meraih dukungan yang berkelanjutan dan menikmati pertumbuhan pangsa pasar, penjualan, dan laba.

Teori pemangku kepentingan menegaskan itu karena kontrak sosial mengikat perusahaan, mereka harus bertindak secara bertanggung jawab dan mengkomunikasikannya kepada berbagai pemangku kepentingan mereka. Aktivitas ISR yang diungkapkan membantu perusahaan menyampaikannya kegiatan dalam memenuhi tanggung jawab mereka pemangku kepentingan. Ini bisa dianggap sebagai sarana komunikasi antara perusahaan dan pemangku kepentingan (Hasan dan Dewi, 2018).

Banyak penelitian untuk mengukur kinerja Bank Umum Syariah di Indonesia terdiri dari banyak aspek, seperti aspek efisiensi menurut Rahmawati dan Hosen (2012), Hosen dan Sutisna (2012), Firdaus dan Hosen (2013), Shafitranata dan Hosen (2014). ), Muhari dan Hosen (2015), Amalia et al. (2015), profitabilitas menurut Hosen (2012), Hosen dan Syukriyah (2012), Abdillah et al. (2016), Hosen dan Rahmawati (2016), Solikhin et al. (2016), dan likuiditas oleh Abdillah et al. (2016), Solikhin dkk. (2016), Hosen dan Muhari (2017).

Antonio dkk. (2012), Asutay dan Harningtyas (2015), Al-Mubarak dan Osmani (2010), dan Soleh (2016) menggunakan MSI dalam penelitiannya untuk mengukur tingkat kinerja bank syariah di beberapa negara dan menentukan peringkat bank syariah dari yang terbaik hingga yang terburuk. Desain penelitian yang sama dilakukan oleh Fauziah dan Yudho (2013), yang mengukur dan memeringkat bank syariah berdasarkan Indeks ISR. Penelitian lain Sunarsih dan Ferdiyansyah (2017) meneliti faktor-faktor yang mempengaruhi perubahan Indeks Islamic Social Reporting pada Bank Syariah di Indonesia.

Penelitian sebelumnya menyatakan bahwa pengukuran kinerja keuangan bank syariah harus didasarkan pada ajaran Islam dan praktik Islam yang diwakili oleh MSI dan ISR. Penelitian ini bertujuan untuk mengukur pengaruh MSI dan ISR terhadap profitabilitas, dimana MSI dan ISR merupakan variabel independen yang belum pernah digunakan pada penelitian sebelumnya. Penelitian ini diharapkan memberikan gambaran bagaimana pengaruh variabel syariah dalam meningkatkan kinerja keuangan bank syariah khususnya untuk mengukur tingkat profitabilitas.

\section{Maqasid Sharia Index (MSI)}

Mohammed dkk (2008) telah mengembangkan evaluasi kinerja untuk perbankan syariah berdasarkan maqashid index yang merujuk pada konsep maqashid syariah Abu Zahrah. Maqashid syariah ini terbagi menjadi 3 variabel yaitu Pendidikan Individu (Tahdzib alNafs), Establishing Justice (Iqamah Al-Adl), dan Maslahah (Welfere). Kemudian, dari 3 variabel tersebut ditransformasikan menjadi sepuluh rasio kinerja.

Tujuan pertama, Education The Individual (Pendidikan Individu), dimaksudkan bahwa bank syariah harus melakukan pengembangan pengetahuan dan keahlian pada individu sehingga nilainilai spiritual meningkat. Dalam hal ini, agar setiap musim bisa menjadi sumber kebaikan bukan sumber keburukan bagi masyarakat lingkungannya. Untuk itu pendidikan ini terbagi menjadi dua, yaitu pendidikan bagi pihak internal dan eksternal bank syariah. Dlam hal ini, dimana pendidikan atau beasiswa, research (penelitian), dan 
masyarakat (eksternal). Selanjutnya, variabel yang pertama ini terdiri dari empat rasio (Mohammed dkk, 2008).

Tujuan kedua, Justice (Keadilan) dimaksudkan bahwa bank syariah harus memastikan kejujuran dan keadilan dalam setiap transaksi dan aktivitas bisnis yang tercakup dalam produk, pricing, dan ketentuan-ketentuan kontrak. Di samping itu, seluruh akad-akad harus bebas dari unsur-unsur ketidakadilan seperti maysir, gharar, dan riba. Oleh sebab itu, variabel yang kedua ini terbagi menjadi tiga rasio, yaitu fair return, functional distribution, dan interest free product (Mohammed dkk, 2008).

Tujuan ketiga, Maslahah (Kesejahteraan), dimaksudkan bahwa bank syariah harus mengembangkan proyek-proyek investasi dan jasa sosial untuk meningkatkan kesejahteraan masyarakat. Karena maslahah (kesejahteraan) merupakan aspek penting bagi kehidupan manusia, sehingga aspek ini turut menjadi perhatian yang utama khususnya dalam industri perbankan syariah. Maslahah (kesejahteraan) ini juga selain memberikan manfaat bagi masyarakat, juga memberikan manfaatnya pada bank syariah itu sendiri. Selanjutnya, variabel yang ketiga ini terbagi menjadi tiga rasio yaitu profit return, personal income transfer (zakat), dan investment in real sector (Mohammed dkk, 2008).

Tabel 1. Rata-rata Bobot Nilai dari Tiga Tujuan Syariah dan 10 Elemen Maqashid Indeks.

\begin{tabular}{lclc}
\multicolumn{1}{c}{ Tujuan } & $\begin{array}{l}\text { Rata-Rata } \\
\text { Bobot (Dari } \\
\text { 100\%) }\end{array}$ & \multicolumn{1}{c}{ Elemen - Elemen } & $\begin{array}{c}\text { Rata - Rata } \\
\text { Bobot (Dari } \\
\mathbf{1 0 0 \%})\end{array}$ \\
01. Pendidikan & 30 & E1. Hibah Pendidikan & \\
(Tadhib al- & & E2. Penelitian & 24 \\
Fard) & & E3. Pelatihan & 27 \\
& & E4. Publikasi & 26 \\
& & Total & 23 \\
02.Menciptakan & 41 & E5. Pengembalian Yang Adil & $\mathbf{1 0 0}$ \\
Keadilan (Ad- & & E6. Fungsi Distribusi & 30 \\
'Adl) & & E7. Produk Non-Bunga & 32 \\
& & Total & 38 \\
03. & & E8.Rasio Keuntungan & $\mathbf{1 0 0}$ \\
Kepentingan & 29 & E9.Pendapatan Personal & 33 \\
Umum & & E10.Rasio Investasi pada & 30 \\
& & sektor Riil & 27 \\
\multicolumn{1}{c}{ Total } & & Total $\quad$ Total & $\mathbf{1 0 0}$ \\
\hline
\end{tabular}

\section{Indeks Pengungkapan Islam (Islamic Disclosure Index)}

Dalam menjalankan usahanya, setiap perusahaan termasuk bank memiliki tanggung jawab sosial kepada masyarakat terkait dengan operasional bisnis meliputi aspek ekonomi (profit), sosial (people), dan lingkungan (planet) atau biasa disebut triple bottom line (3P), yang tertuang dalam Corporate Social Responsibility (CSR).

Bank syariah sebagai perusahaan syariah memiliki tanggung jawab sosial kepada masyarakat, terutama terkait dengan nilai-nilai Islam yang terkait dengan aktivitasnya. Hal ini terlihat dari pengungkapan Islamic Social Reporting (ISR) yang diperoleh dari laporan tahunan. Nilai ISR diperoleh dari laporan tahunan perusahaan dengan menggunakan 
analisis konten. Indeks ISR yang digunakan dalam penelitian ini mengacu pada Indeks ISR yang dilakukan oleh Fauziah dan Yudho (2013), Lestari (2013) dan Asutay dan Harningtyas (2016) dengan beberapa penyesuaian (Hosen, et al.,2019).

Islamic social reporting atau Index ISR yaitu standar pengungkapan sosial yang sejalan dengan prinsip-prinsip syariah. ISR memiliki isi kompilasi atas item-item parameter tanggungjawab sosial yang ditetapkan oleh sebuah lembaga internasional yang independen yaitu Accounting and Auditing Organization for Islamic Financial Instituions. Indeks tersebut berisi berbagai macam hal yang terkait dengan pedoman islam, yaitu adanya transaksi bebas dari riba, tidak adanya spekulasi atau ketidakpastian, adanya pengungkapan mengenai zakat, adanya pengakuan mengenai aspek syariah dan aspek sosial seoerti shodaqoh, waqaf dan lainsebagainya (Mardliyyah dkk, 2020).

Indeks ISR dikembangkan oleh Othman (2009), indeks ini merupakan tolak ukur penerapan tanggung jawab sosial perusahaan syariah yang memuat kompilasi item standar CSR. Islamic Social Reporting (ISR) terdiri atas item-item standar CSR yang ditetapkan oleh AAOFI (Accounting and Auditing Organization for Islamic Institutions) lalu dikembangkan lagi oleh para peneliti mengenai item- item CSR yang patut diungkapkan oleh suatu entitas Islam. Indeks tersebut berisi 6 tema antara lain: investasi dan keuangan, produk dan jasa, karyawan, masyarakat, lingkungan serta tata kelola perusahaan. Masingmasing tema memiliki indikator, seluruhnya berjumlah 48 indikator.

\section{Profitabilitas}

Return On Asset (ROA) adalah rasio yang mencerminkan kemampuan perusahaan dalam menghasilkan laba yang didasarkantotal asset tertentu pada perusahaan (Hanafi \& Halim, 2014:82). Menurut Hantono (2018) Return on Asset atau Return on Investment yaitu rasio yang menunjukkan tingkat pengembalian bisnis dari seluruh investasi yang telah dilakukan. Dengan kata lain, rasio ini digunakan untuk mengukur seberapa besar jumlah laba bersih yang akan dihasilkan dari setiap rupiah dana yangtertanam dalam total asset.

Rasio ini dihitung dengan membagi laba bersih terhadap total asset. Semakin tinggi hasil pengembalian aset semakin tinggi pula jumlah laba bersih yang dihasilkan dari setiap rupiah dana yang tertanam dalam total aset, begitu pun sebaliknya. Dalam perhitungan ROA satuan yang digunakan yaitu persentase.

\section{METODOLOGI PENELITIAN}

\section{a. Data dan Sampel}

Penelitian ini menguji faktor-faktor yang mempengaruhi profitabilitas bank syariah, dengan variabel Maqasid Sharia Index dan Index of Islamic Social Reporting (ISR) dari tahun 2016 sampai 2019. Bank syariah dalam penelitian ini adalah Bank Umum Syariah di Indonesia. Data yang digunakan dalam penelitian ini adalah data sekunder. Data tersebut di peroleh dari laporan tahunan masing - masing bank syariah dari tahun 2016 - 2019 yang bersumber dari website resminya.

\section{b. Variabel Penelitian}

RAAR

Vol.2 No.1

\section{Variabel Independen}

1. Maqashid syariah index 
Pengukuran Maqashid Syariah Index oleh Mohammed et al. (2008) yang menyesuaikan dari konsep maqashid syariah yang dijelaskan oleh Abu Zahrah, yaitu Tahdīb al-Fard, Iqāmah al-'Adl, dan Jalb al-Maslahah ( Hosen, et al.,2019).

\section{Islamic Social Reporting}

Indeks ISR dalam penelitian ini terdiri dari 48 item pengungkapan yaitu terstruktur dalam enam tema. Setiap item disclosure yang terdapat dalam laporan tahunan akan diberi nilai 1 , bank syariah mendapatkan nilai maksimal 100 jika memiliki semua item disclosure. Rumus untuk mendapatkan indeks ISR dapat dijelaskan sebagai berikut:

$$
\text { Islamisc Disclosure }=\underline{\text { disclosure item }} \times 100 \%
$$

\section{Variabel dependen}

Variabel terikat dalam penelitian ini adalah return on asset (ROA) yang merupakan salah satu indikator profitabilitas. ROA digunakan untuk mengukur efektivitas Bank Islam dalam menghasilkan laba dari aset yang dimiliki. Rumus untuk menghitung ROA adalah:

\section{c. Teknik Analisis Data}

$$
\mathrm{ROA}=\frac{\text { laba bersih }}{\text { Total aset }}
$$

Penelitian ini menggunakan teknik analisis regresi berganda karena variabel independen dalam penelitian lebih dari dua. Teknik ini digunakan untuk mengetahui hubungan dan seberapa besar pengaruh dari variabel variabel bebas (independen) terhadap variabel terikat (dependen).

\section{HASIL PENGUJIAN HIPOTESIS}

\section{Uji Asumsi Klasik}

\section{a. Uji Normalitas}

Uji normalitas menggunakan uji Kolmogorov Smirnov dengan menggunakan bantuan program statistik. Dasar pengambilan keputusan yaitu jika probabilitas lebih besar atau sama dengan dari nilai alpha yang ditentukan, yaitu 5\%, maka data dikatakan berdistribusi normal, dan sebaliknya jika probabilitas kurang dari 5\%, maka data tidak berdistribusi normal.

Tabel 2.

One-Sample Kolmogorov-Smirnov Test

\begin{tabular}{|l|l|r|}
\hline \multicolumn{2}{|l|}{} & Unstandardized Residual \\
\hline N & 14 \\
\hline \multirow{2}{*}{ Normal Parameters } & Mean &, 0000000 \\
\cline { 2 - 3 } & Std. Deviation & 2,49844948 \\
\cline { 2 - 3 } & Absolute &, 147 \\
\cline { 2 - 3 } & Positive &, 128 \\
\cline { 2 - 3 } & Negative &,- 147 \\
\hline Test Statistic &, 147 \\
\hline Asymp. Sig. (2-tailed) &, $200^{\mathrm{c}, \mathrm{d}}$ \\
\hline
\end{tabular}


b. Calculated from data.

c. Lilliefors Significance Correction.

d. This is a lower bound of the true significance.

Dari hasil pengujian menunjukkan bahwa, nilai asymp. Sig 0,20, artinya lebih besar dari dari 0,05 sehingga disimpulkan data berdistribusi normal.

\section{b. Uji Autokorelasi}

Uji autokorelasi bertujuan untuk menguji apakah dalam model regresi ada korelasi antara kesalahan penggunaan pada periode $t$ dengan kesalahan penggunaan periode $t-1$ (sebelumnya).

Tabel 3. Uji Autokorelasi

\begin{tabular}{|c|c|c|c|c|c|}
\hline Model Summary \\
\hline Model & R & R Square & $\begin{array}{c}\text { Adjusted R } \\
\text { Square }\end{array}$ & $\begin{array}{c}\text { Std. Error of } \\
\text { the Estimate }\end{array}$ & $\begin{array}{c}\text { Durbin- } \\
\text { Watson }\end{array}$ \\
\hline 1 &, $853^{\text {a }}$ &, 727 &, 677 & 2,71610 & 2,326 \\
\hline \multicolumn{7}{|c|}{ a. Predictors: (Constant), ISR, MSI } \\
\hline b. Dependent Variable: Profitabilitas \\
\hline
\end{tabular}

Dari hasil uji Durbin Watson tes diatas, diperoleh angka sebesar 2,326 lebih besar dari batas atas (du) sebesar 1,254, dan kurang dari 2(total variabel independen)1,254 atau sebesar 1,072. Maka disimpulkan bahwa tidak terjadi autokorelasi.

\section{c. Uji Multikolinieritas}

Uji multikolinearitas bertujuan untuk menguji apakah dalam model regresi ditemukan adanya korelasi antara variabel independen. Menurut Ghozali (2011), model regresi yang baik seharusnya tidak memiliki korelasi diantara variabel independen. Jika terdapat korelasi yang tinggi variabel independen tersebut, maka hubungan antara variabel independen dan variabel dependen menjadi terganggu. Ada tidaknya multikolinearitas dalam model regresi dilihat dari Variance Inflation Factor (VIF) dan nilai Tollerance $(\mathrm{T})$. Jika nilai VIF $<10$ dan nilai $\mathrm{T}>0,01$, maka tidak terjadi multikolinearitas.

Tabel 4. Uji Multikolinearitas

Coefficients $^{\mathbf{a}}$

\begin{tabular}{|c|c|c|c|c|c|c|c|c|}
\hline \multirow{2}{*}{\multicolumn{2}{|c|}{ Model }} & \multicolumn{2}{|c|}{$\begin{array}{c}\text { Unstandardized } \\
\text { Coefficients }\end{array}$} & \multirow{2}{*}{$\begin{array}{c}\begin{array}{c}\text { Standardize } \\
\mathrm{d} \\
\text { Coefficient } \\
\mathrm{s}\end{array} \\
\\
\text { Beta } \\
\end{array}$} & \multirow[b]{2}{*}{$\mathrm{t}$} & \multirow[b]{2}{*}{ Sig. } & \multicolumn{2}{|c|}{$\begin{array}{c}\text { Collinearity } \\
\text { Statistics }\end{array}$} \\
\hline & & $\mathrm{B}$ & $\begin{array}{l}\text { Std. } \\
\text { Error }\end{array}$ & & & & \begin{tabular}{|c} 
Toleranc \\
$\mathrm{e}$
\end{tabular} & VIF \\
\hline \multirow[t]{3}{*}{1} & (Constant) & $-22,418$ & 16,687 & & $-1,343$ & ,206 & & \\
\hline & $\mathrm{X} 1$ & 12,313 & 26,418 & ,127 &, 466 &, 650 & ,334 & 2,998 \\
\hline & $\mathrm{X} 2$ & 42,765 & 15,637 & ,746 & 2,735 & ,019 & ,334 & 2,998 \\
\hline
\end{tabular}

Dari hasil pengujian diatas nilai tolerance lebih besar dari 0,01 dan VIF kurang dari 10, maka disimpulkan tidak terjadi gejala mulitkolinearitas.

\section{d. Uji Heteroskedastisitas}


Uji heteroskedastisitas bertujuan menguji apakah dalam model regresi terjadi ketidaksamaan varians residual dari satu pengamatan ke pengamatan yang lain (Ghozali, 2011). Dalam penelitian ini menggunakan Uji Glejser

Tabel 6. Uji Heterokedastisitas

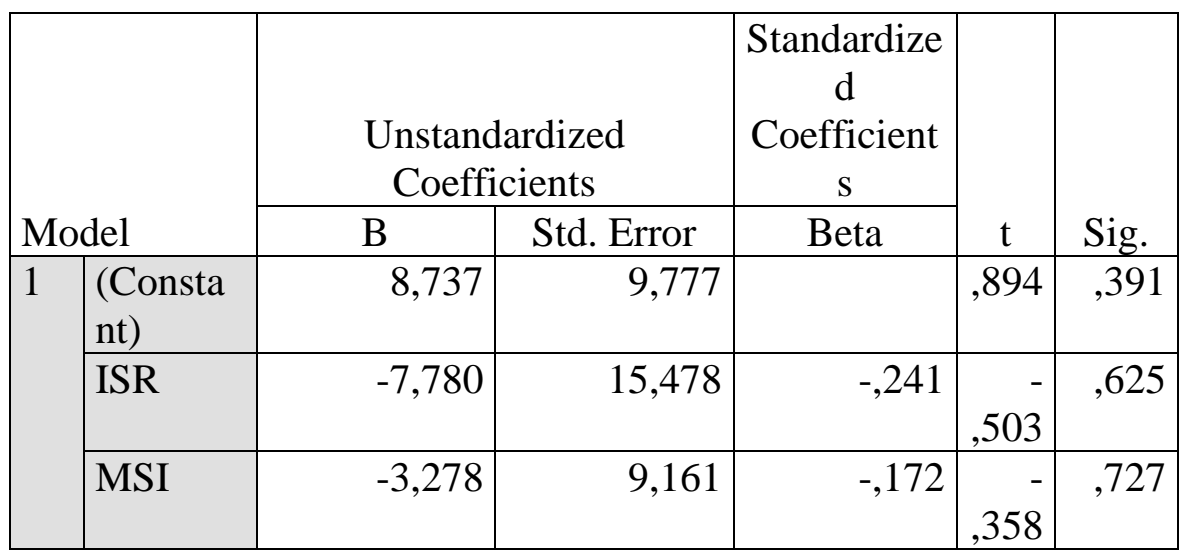

Dari hasil pengujian diatas probabilitas signifikansinya diatas tingkat kepercayaan sebesar $5 \%$, atau 0,05 . Sehingga disimpukan tidak terjadi gejala heterokedastisitas.

\section{Uji Hipotesis}

\section{a. Uji koefisien Determinasi}

Tabel 5. Adjusted $\mathrm{R}^{2}$

\begin{tabular}{|c|c|c|c|c|c|}
\hline Model & $\mathrm{R}$ & $\mathrm{R}$ Square & $\begin{array}{c}\text { Adjusted R } \\
\text { Square }\end{array}$ & $\begin{array}{c}\text { Std. Error of } \\
\text { the Estimate }\end{array}$ & $\begin{array}{c}\text { Durbin- } \\
\text { Watson }\end{array}$ \\
\hline 1 &, $853^{\mathrm{a}}$ &, 727 &, 677 & 2,71610 & 2,326 \\
\hline
\end{tabular}

Dari hasil pengujian adjusted $\mathrm{R}^{2}$ diperoleh angka sebesar 0,667 atau 66,7\% . hal ini berarti 66,7\% variasi Profitabilitas dapat dijelaskan oleh kedua variabel independennya, sedangkan sisanya dijelaskan oleh sebab sebab lain diluar model diatas.

\section{b. Uji Signifikansi Parameter Individual (Uji t)}

Hasil uji statistik t dapat dilihat pada tabel berikut :

Tabel 6. Hasil uji parameter individual (uji t)

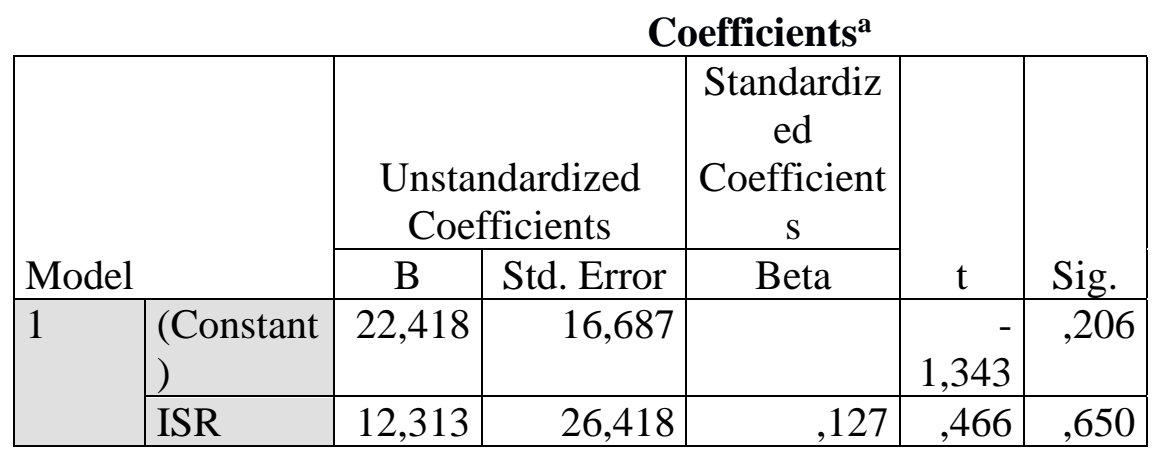




\begin{tabular}{|l|r|r|r|r|r|}
\hline MSI & 42,765 & 15,637 &, 746 & 2,735 &, 019 \\
\hline
\end{tabular}

a. Dependent Variable: Profitabilitas

Berdasarkan Tabel diatas maka dapat dibentuk persamaan regresi linear berganda sebagai berikut:

\section{Profitabilitas $=-22.418+12.313$ ISR + 42,765 MSI + e}

1. Nilai konstanta sebesar $-22,418$ menunjukkan bahwa apabila variabel maqashid syariah index dan Islamic Social Reporting bernilai 0 maka nilai profitabilitas bank syariah akan memiliki nilai sebesar $-2241,8 \%$.

2. Nilai koefisien variabel Islamic Social Reporting sebesar 12,313 menunjukkan setiap peningkatan 1 Islamic Social Reporting maka akan menaikkan nilai profitabilitas bank syariah sebesar 1231,3 dengan asumsi variabel lainnya dianggap bernilai 0 .

3. Nilai koefisien variabel maqahid syariah index sebesar 42,765 menunjukkan setiap peningkatan 1 maqahid syariah index maka akan menaikkan nilai profitabilitas bank syariah sebesar 4276,5 dengan asumsi variabel lainnya dianggap bernilai 0

Dari tabel diatas, diperoleh hasil pengujian hipotesis sebagai berikut;

Hipotesis 1; Islamic Social Reporting berpengaruh positif terhadap profitabilitas bank umum syariah di Indonesia.

Berdasarkan Tabel diatas, hasil uji parsial pengaruh Islamic Social Reporting terhadap

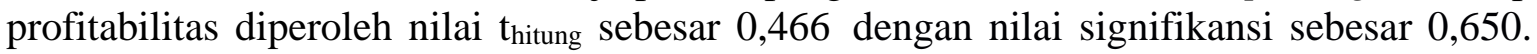
Karena nilai signifikansi lebih dari 0,05 maka dapat disimpulkan bahwa variabel Islamic social reporting tidak berpengaruh terhadap profitabilitas sehingga dapat dikatakan bahwa hipotesis pertama yang menyatakan islamic social reporting berpengaruh positif terhadap profitabilitas bank umum syariah di tolak.

\section{Hipotesis 2 : Maqashid syariah index berpengaruh positif terhadap profitabilitas bank umum syariah di Indonesia}

Berdasarkan Tabel diatas, hasil uji parsial pengaruh maqashid syariah index terhadap profitabilitas diperoleh nilai thitung sebesar 2,735 dengan nilai signifikansi sebesar 0,019. Karena nilai signifikansi lebih dari 0,05 maka dapat disimpulkan bahwa variabel maqashid syariah index berpengaruh positif terhadap profitabilitas sehingga dapat dikatakan bahwa hipotesis pertama yang menyatakan maqashid syariah index berpengaruh positif terhadap profitabilitas bank umum syariah di terima.

\section{SIMPULAN DAN SARAN}

ISR atau Index ISR yaitu standar pengungkapan sosial yang sejalan dengan prinsip-prinsip syariah. ISR memiliki isi kompilasi atas item-item parameter tanggungjawab sosial yang ditetapkan oleh sebuah lembaga internasional yang independen yaitu Accounting and Auditing Organization for Islamic Financial Instituions.

Hasil penelitian ini sejalan dengan penelitian yang dilakukan oleh Zuliana dan Aliamin (2019), Arifin dan Wardani (2016)yang menyatakan bahwa ISR tidak berpengaruh

\section{RAAR}

Vol.2 No.1 terhadap kinerja bank syariah di Indonesia, yang diproksikan dengan ROA.

Berbeda dengan Hasil penelitian diatas, oleh Adisaputra (2016) dan Harahap (2017), Santika (2019) juga membuktikan secara empiris bahwa Islamic social reporting berpengaruh secara signifikan terhadap profitabilitas (ROA) bank umum syariah. 
Pengukuran kinerja bagi perbankan syariah harusnya berbeda dengan pengukuran kinerja bank konvensional. Karena bank syariah dalam operasionalnya menggunakan prinsip syariah, yang membedakan dengan bank konvensional. Dalam pengukuran kinerja bank syariah ini tidak hanya berfokus pada laba dan ukuran keuangan lainnya, tetapi memasukkan nilai-nilai syariah dari perbankan yang mencerminkan ukuran manfaat non profit yang sesuai dengan tujuan bank syariah. Dalam prinsip syariah yang disebut maqashid syariah index (MSI). Model MSI ini telah banyak digunakan dalam penelitian untuk mengukur kinerja perbankan syariah di berbagai Negara termasuk di Indonesia. Beberapa penelitian yang menggunakan maqashid syariah index pada perbankan syariah yaitu Muhamed \& Dzuljastri (2008), Sudrajat \& Sodiq (2016), Firmansyah (2018), Rusydiana \& Firmansyah (2018).

Hasil penelitian ini bahwa Maqasid syariah index (MSI) berpengaruh positif terhadap profitabilitas. Hasil ini sejalan dengan penelitian Berlianti dan Ruhadi (2018), Maulina dan Kustyaningsih (2019), pratiwi dan setiawan (2019).

Maqasid syariah index (MSI) dikembangkan berdasarkan tiga faktor utama yaitu pendidikan individu, penciptaan keadilan, dan pencapaian kesejahteraan, dimana tiga faktor tersebut sesuai dengan tujuan umum maqasid syariah yaitu "mencapai kesejahteraan dan menghindari keburukan". Ketiga tujuan ini bersifat universal yang seharusnya menjadi tujuan dan dasar operasional setiap entitas berakuntabilitas publik, tidak hanya bank syariah tetapi juga bank konvensional, karena berkaitan dengan kesejahteraan bagi semua pemangku kepentingan, bukan hanya pemegang saham atau pemilik perusahaan.

Dalam penelitian ini membuktikan bahwa maqashid syariah indeks (MSI) berpengaruh positif dan signifikan terhadap profitabilitas bank umum syariah. Hal ini menunjukkan bahwa, penerapan MSI mampu meningkatkan profitabilitas bank umum syariah. Artinya, semakin tinggi penerapan MSI akan akan meningkatkan profitabilitas bank umum syariah. Selain itu, penerapan MSI tidak menganggu perusahaan dalam memperoleh laba. Oleh karena itu, penerapan prinsip syariah dalam perbankan memberikan jaminan bahwa perusahaan tidak semata-mata harus mengejar profit, tapi juga memberi pendidikan individu, penciptaan keadilan, dan pencapaian kesejahteraan bagi penggunanya.

\section{REFERENSI}

Abdillah, Rahmat, Muhamad Nadratuzzaman Hosen \& Syafaat Muhari. 2016. "The Determinant Factor of Islamic Bank's Profitability and Liquidity in Indonesia." Knowledge Horizons-Economics 8(2): 140-147.

Afrinaldi. 2013. "Analysis of Islamic Banking Performance based on Maqasid Shariah: Maqasid Shariah Index and Profitability Approaches." Paper Presented at Islamic Economics and Finance Research Forum II, Jakarta November 12nd-13rd.

Al-Mubarak, Tawfique \& Noor Mohammad Osmani. 2010. "Applications of Maqasid alShari'ah and Maslahah in Islamic Banking practices: An analysis." In International Seminar on Islamic Finance in India: 4-6.

Antonio, Muhammad Syafii, Yulizar D Sanrego \& Muhammad Taufi. 2012. "An Analysis of Islamic Banking Performance: Maqasid Index Implementation in Indonesia and Jordania." Journal of Islamic Finance 1(1): 12-29.

Bahsoan, Agil. 2011. "Mashlahah as Maqasid al-Shari’ah.” Inovasi 8(1): 113-132.

RAAR

Vol.2 No.1 
Bungin, Burhan. 2005. Quantitative Research Methodology: Communication, Economics, and Public Policy and Other Social Sciences. Jakarta: Kencana.

Dusuki, Asyraf Wajdi \& Nurdianawati Irwani Abdullah. 2007. "Maqasid al-Shari'ah, Maslahah, and Corporate Social Responsibility." The American Journal of Islamic Social Sciences 24(1): 25-45.

Fauziah, Khusnul \& Prabowo Yudho Jayanto. 2013. "Analysis of Islamic Social Responsibility Disclosure of Islamic Banking in Indonesia Based on Islamic Social Reporting Index.” Jurnal Dinamika Akuntansi, 5: 12-20.

Firdaus, Muhammad Faza \& Muhamad Nadratuzzaman Hosen. 2013. "Measurement of Efficiency and Soundness of Islamic Bank Using Two-Stage Data Envelopment Analysis and Modified CAMELS." Journal of Islamic Banking and Finance 30(3): 32-48.

Ghozali, Imam dan Chariri, Anis. 2007. Teori Akuntansi, Edisi 3, Universitas Diponegoro, Semarang.

Hadi, Kuncoro. 2012. "Implementation of Maqasid Shariah as Islamic Corporate Indicator.” Al-Azhar Indonesia Seri Pranata Sosial 1(3): 140-150.

Hasan dan Dewi, 2018. Maqashid Shariah-Based Performance and Islamic Social Responsibility; An Empirical Study of Islamic Bank in Asean. Advances in Economics, Business and Management Research, volume 101

Herianingrum, Sri. 2014. "Implementation of Maqasid Al Sharia as a Model of Economic Development Agriculture in East Java." Paper Presented at International Conference on Business, Economics and. Accounting II Hongkong, 26-28 March.

Hosen, Muhamad Nadratuzzaman. 2012. "Factors that Affect the Profitability of the Conventional Bank and Shariah Bank in Indonesia." Journal of Islamic Banking and Finance 29(2): 55-68.

Hosen, Muhamad Nadratuzzaman \& Rafika Rahmawati. 2014. "Analysis of Efficiency, Profitability, and Soundness of Islamic Commercial Banks in Indonesia between 2010 and 2013." Finance and Banking Journal 16(2): 207-227.

Hosen, Muhamad Nadratuzzaman \& Syafaat Muhari. 2014. Analysis of The Efficiency Level of Shariah Rural Bank in Indonesia using DEA and its correlation with CAMEL. Journal of Islamic Banking and Finance 31(4): 80-102.

Hosen, et al.,2019.. The Effect of Financial Ratios, Maqasid Sharia Index, and Index of Islamic Social Reporting to Profitability of Islamic Bank in Indonesia. Al-Iqtishad: Jurnal Ilmu Ekonomi Syariah (Journal of Islamic Economics) Volume 11 (2), July 2019

Hutagalung, Esther Novelina, Djumahir \& Kusuma Ratnawati. 2013. "The Influence of Financial Ratios to Performance of Commercial Banks in Indonesia." Jurnal Aplikasi

Imaniah, Nia. 2014. "The Effect of Islamic Social Reporting Disclosure, Financial Performance, and Public Ownership to Corporate Value (Empirical Study from Listed Company at Jakarta Islamic Index between 2010 and 2013).” Bachelor Degree Thesis. State Islamic University of Jakarta, Indonesia. 
Laldin, Mohamad Akram. 2010. "Maqasid Shari'ah as Based of Equal Economics System." Paper Presented at Seminar Maqasid Syariah: Menggagas Model Ekonomi Berkeadilan Sempena Ijimak Harakiy Pertama WADAH-ABIM-PKPIM at GermanMalaysian Institute, Kajang, Malaysia, August 7 th.

Lestari, Puji. 2013. "Determinants of Islamic Social Reporting in Syariah Banks: Case of Indonesia." International Journal of Business and Management Invention 2(10): 28-34. Maali, Bassam, Peter Casson \& Christopher Napier. 2006. "Social Reporting by Islamic Banks." ABACUS 42(2): 266-289.

Mutia dan Musfirah, 2017. Pendekatakan maqashid syariah indeks sebagai pengukuran kinerja perbankan syariah di Asia tenggara. Jurnal Akuntansi dan Keuangan Indonesia. Vol.14 No.2 Desember 2017.

Mohammed, Mustafa Omar dan Dzuljastri Abdul Razak. 2008. "The Performance Measures of Islamic Banking Based on the Maqasid Framework". Malaysia: Journal of Internasional

Mohammed, Mustafa omar \& Taib, Fauziah.2015. developing Islamic banking Performance measured based on maqashid al Syariah framework: Cases of 24 Selected banks. Journal of Islamic Monetary economics and finance. August 2015

Pratiwi, Leni dan Setiawan. Pengaruh implementasi good corporate governance dan maqashid al-syariah terhadap Profitabilitas Pada bank umum syariah. sigmamu Vol 11 No 2 (2019). 